\title{
Properties of Convectively Induced Turbulence over Developing Oceanic Convection
}

\author{
KATELYN A. BARBER \\ University of North Dakota, Grand Forks, North Dakota \\ WIEBKE DEIERLING \\ National Center for Atmospheric Research, Boulder, Colorado \\ GRETCHEN MULLENDORE \\ University of North Dakota, Grand Forks, North Dakota \\ CAthy Kessinger, Robert Sharman, And Domingo Muñoz-Esparza \\ National Center for Atmospheric Research, Boulder, Colorado
}

(Manuscript received 26 November 2018, in final form 23 May 2019)

\begin{abstract}
Convectively induced turbulence (CIT) is an aviation hazard that continues to be a forecasting challenge as operational forecast models are too coarse to resolve turbulence affecting aircraft. In particular, little is known about tropical maritime CIT. In this study, a numerical simulation of a tropical oceanic CIT case where severe turbulence was encountered by a commercial aircraft is performed. The Richardson number (Ri), subgrid-scale eddy dissipation rate (EDR), and second-order structure functions (SF) are used as diagnostics to determine which may be used for CIT related to developing and mature convection. Model-derived subgrid-scale EDR in past studies of midlatitude continental CIT was shown to be a good diagnostic of turbulence but underpredicted turbulence intensity and areal coverage in this tropical simulation. SF diagnosed turbulence with moderate to severe intensity near convection and agreed most with observations. Further, SF were used to diagnose turbulence for developing convection. Results show that the areal coverage of turbulence associated with developing convection is less than mature convection. However, the intensity of turbulence in the vicinity of developing convection is greater than the turbulence intensity in the vicinity of mature convection highlighting developing convection as an additional concern to aviation.
\end{abstract}

\section{Introduction}

Convectively induced turbulence (CIT) continues to be a prediction challenge for global aviation operations. Important generation mechanisms for out-of-cloud CIT are 1) the enhancement of the background wind shear by convection penetrating into the upper troposphere, 2) cloud-induced deformation at the cloud boundary caused by buoyancy gradients, and 3) convectively generated gravity waves that propagate and break above convection (Lane et al. 2003). In-cloud CIT is caused by moist instabilities and mixing near updrafts, downdrafts,

Corresponding author: Katelyn A. Barber, katelyn.barber@ und.edu and anvil cloud features (Lane et al. 2003). While operational forecasting systems are trending toward finer resolutions (Smith et al. 2008), turbulence scales that are affecting aircraft are not resolved in current operational numerical weather prediction models (Lane and Reeder 2001; Lane et al. 2003; Trier and Sharman 2009; Lane et al. 2012; Trier and Sharman 2016). To mediate the resolution dependency, many turbulence prediction products rely on empirical indices that have been designed to diagnose large-scale fields that relate to turbulent sources from numerical simulations (Endlich 1964; Brown 1973; Buldovskii et al. 1976; Dutton 1980; Keller 1990; Ellrod and Knapp 1992; Bluestein 1993; Vogel and Sampson 1996; Knox 2001; Sharman et al. 2006; Ellrod and Knox 2010; Sharman and Pearson 2017; 
Sharman and Trier 2019; Muñoz-Esparza and Sharman 2018). However, most of the indices were developed and calibrated for the midlatitudes and many do not include the sources of convectively induced turbulence. Some studies have examined CIT encounters through dedicated numerical simulations in more detail. These studies have led to some advancement in our understanding of CIT but more research needs to be done to fully understand all physical processes that lead to convection related turbulence. Furthermore, the majority of these studies have been limited to mature convection in the midlatitudes (Lane et al. 2003; Koch et al. 2005; Lane and Sharman 2008; Trier and Sharman 2009; Lane et al. 2009; Lane et al. 2012; Trier et al. 2012; Lane and Sharman 2014; Zovko-Rajak and Lane 2014; Trier and Sharman 2016; Barber et al. 2018). Because the scientific research on turbulence associated with tropical convection (developing and mature) is sparse, aviation operations in tropical regions abide by thunderstorm avoidance policies designed from research of mature midlatitude convection. The Federal Aviation Administration (FAA) in the United States set policies that include a lateral avoidance of $20 \mathrm{mi}(32.2 \mathrm{~km})$ from severe convection (U.S. Department of Transportation; FAA 2017).

While consistency in operations between the midlatitudes and tropics may reduce the number of guidelines needed to avoid convective hazards, it could also be inefficient for flight routing and planning when tropical convection is significantly different than midlatitude convection. It is commonly understood that there are some significant dynamical and physical differences between the convection populations that occur in the continental midlatitudes and maritime tropics (Chin et al. 1995; Liu and Zipser 2005; Yuter et al. 2005; Vant-Hull et al. 2016). Key differences in the convective populations that would impact the frequency and hazard potential of CIT include maximum vertical velocities of updrafts, the maximum height of convection and the probability of convection overshooting into the stratosphere, and the diurnal variation of convection. There is also a difference in the stability and shear profiles of the tropical and midlatitude environments. Generally, vertical wind shear is lower in the tropical environment (Wissmeier and Goler 2009) and moist static stability is less (Saha and Singh 1972; Garstang and Fitzjarrald 1999; Frierson 2006; Frierson and Davis 2011).

Tropical developing convection poses a challenge to aviation because nowcasting products used for the identification of developing convection are limited temporally and spatially. Current operational forecasting systems also have difficulties accurately predicting the location and timing of developing convection. Due to

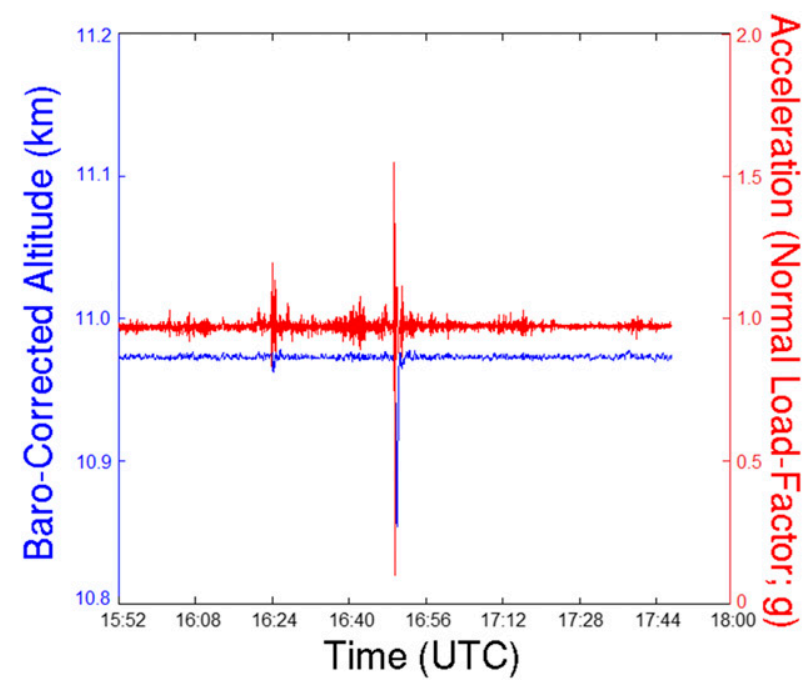

FIG. 1. Baro-corrected altitude $(\mathrm{km})$ and acceleration $(\mathrm{g})$ recorded by the aircraft from 1552 to 1800 UTC.

these numerous challenges associated with developing convection, hazards to aviation operations are not completely understood and no specific FAA or ICAO (International Civil Aviation Organization) avoidance guidelines exist. Pilots do have onboard radar systems that can detect developing convection. However, the operation and tilt management of the radar at cruising altitude is at the discretion of the pilot, which can lead to unexpected CIT encounters when onboard radar is improperly used (M. Poellot 2018, personal communication; Marconnet et al. 2016; AIRBUS 2007).

In this study, a numerical simulation of a severe turbulence encounter is compared against observations and in situ measurements of turbulence. Indices commonly used for turbulence prediction are used as turbulence diagnostics and examined during time periods near the turbulence encounter. Indices that perform well for the convective environment are used to analyze turbulence during the developing and mature stages of the convective cycle to understand the influences of convective stage on turbulence.

\section{Turbulence incident in the southern Gulf of Mexico: 20 June 2017}

On 20 June 2017, a commercial aircraft (Boeing 737) traveling from Panama City, Panama, to Houston, Texas, at approximately $11 \mathrm{~km}$ cruising altitude encountered severe turbulence 90 miles east of Cancun, Mexico. The encounter occurred at 1651 UTC near $21.84^{\circ} \mathrm{N},-86.16^{\circ} \mathrm{E}$. During the encounter the aircraft experienced normal load factors of -0.73 to $1.6 \mathrm{~g}$ for approximately $20 \mathrm{~s}$ and decreased in altitude by $120 \mathrm{~m}$ (Fig. 1). Nine passengers 


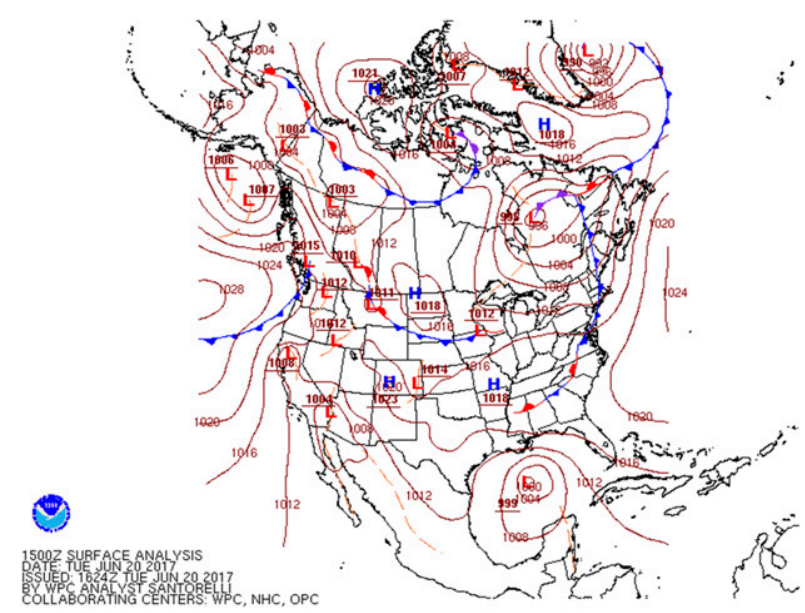

FIG. 2. 1500 UTC surface analysis issued by the Weather Prediction Center.

and one crew member sustained injuries and received medical attention. Synoptically, the jet stream was located north of $37^{\circ} \mathrm{N}$ and was in a zonal flow pattern with a jet streak located west of Washington State over the Pacific Ocean (CIMSS, NOAA, WPC, College of Dupage, not shown here). Winds aloft over the Gulf of Mexico were weak and had a northerly component along the flight trajectory. There were enhanced regions of vertical wind shear over the Gulf of Mexico between the 350 and $200 \mathrm{mb}(9.7$ and $11 \mathrm{~km})$ and speed shear of $30-40 \mathrm{kts}\left(1 \mathrm{kt} \approx 0.5144 \mathrm{~m} \mathrm{~s}^{-1}\right)$ between the upper (less than $300 \mathrm{mb}$ ) and lower atmosphere (greater than $700 \mathrm{mb}$ ). The horizontal gradient of vertical wind shear was oriented almost exactly along the flight trajectory. In addition to wind shear along the flight trajectory, there was deformation and enhanced upper-level divergence. There was also a local maximum of absolute vorticity northeast of the Yucatán Peninsula.

A broad region of low pressure was located over the Gulf of Mexico (Fig. 2). The low pressure center became more organized over the Gulf of Mexico on 20 June and developed into Tropical Storm Cindy by 1800 UTC. An extensive cloud field with embedded deep convection extended east of the low pressure center in the Gulf of Mexico. In relation to the flight path, convection was abundant (see Figs. 3a,b) but satellite imagery and pilot records indicate the aircraft was out of cloud at the time of the incident in a clear region above lower cloud tops. Brightness temperatures calculated from GOES-13 radiances reached minimum temperatures of $190 \mathrm{~K}$ in isolated areas to the west and north of the aircraft around the time of the encounter and near $220 \mathrm{~K}$ in the vicinity of the aircraft (Figs. 3a,b; note that here and in subsequent figures the location of the aircraft at the time of the severe turbulence encounter is indicated with a star symbol).
The convective diagnosis oceanic algorithm (CDO) is a nowcasting tool developed to improve safety and efficiency along transoceanic flights (Table 1; Herzegh 2002). The algorithm has four inputs (observational and numerical) that are used to detect convective hazards and better identify convective structure (Kessinger et al. 2008; Kessinger 2017). These inputs are cloud-top height (CTH) from infrared brightness temperature, the global convective diagnosis, the difference between the brightness temperature of the infrared channel and the brightness temperature of the water vapor channel, GOES-R overshooting tops algorithm, and a 15-min lightning density field. The CDO algorithm estimates convective intensity on a scale of 1-6 every $15 \mathrm{~min}$ and is calculated on a global scale using six geostationary satellites.

CDO identified the Gulf of Mexico as an area with convective hazards. Regions of lightning and overshooting tops near the aircraft at the time of the turbulence incident occurred based on the GOES-R overshooting tops algorithm and Earth Networks lightning data (Figs. 3c-f and 4). Numerous lightning strikes were recorded within $5 \mathrm{~min}$ of the turbulence incident. Echo top heights determined by CDO were estimated to be $10.7 \mathrm{~km}$ near the location of the turbulence encounter at 1700 UTC and greater than $13 \mathrm{~km}$ in isolated cells to the west, south, and north of the aircraft. While CDO performed well for this particular case, it cannot provide forecasting information of convection needed for flight planning operations. The synoptic and mesoscale atmospheric conditions suggest that turbulence was likely convectively induced and enhanced in regions of wind shear. To adequately predict turbulence for this case day, turbulence diagnostics must capture both large scale features such as vorticity, mesoscale features such as stability, deformation, and wind shear, and subgrid scale motions such as turbulent kinetic energy.

\section{Data and methods}

\section{a. Model setup}

In this study, a 24-h hindcast of tropical convection from 20 June 2017 is made using the Advanced Research WRF (ARW) Model, version 3.9 (Skamarock and Klemp 2008). This simulation is initialized at 0000 UTC with 0.25 Degree GFS analysis data (http://rda.ucar.edu/ datasets/ds084.1). One parent and two nested domains are used in this simulation with a horizontal grid spacing of $3 \mathrm{~km}$ in the innermost domain and 100 vertical levels (Fig. 5). The vertical grid spacing between 8 and $12 \mathrm{~km}$ is approximately $325 \mathrm{~m}$. The horizontal resolution of this simulation is comparable to operational modeling systems currently used and the increased vertical resolution 

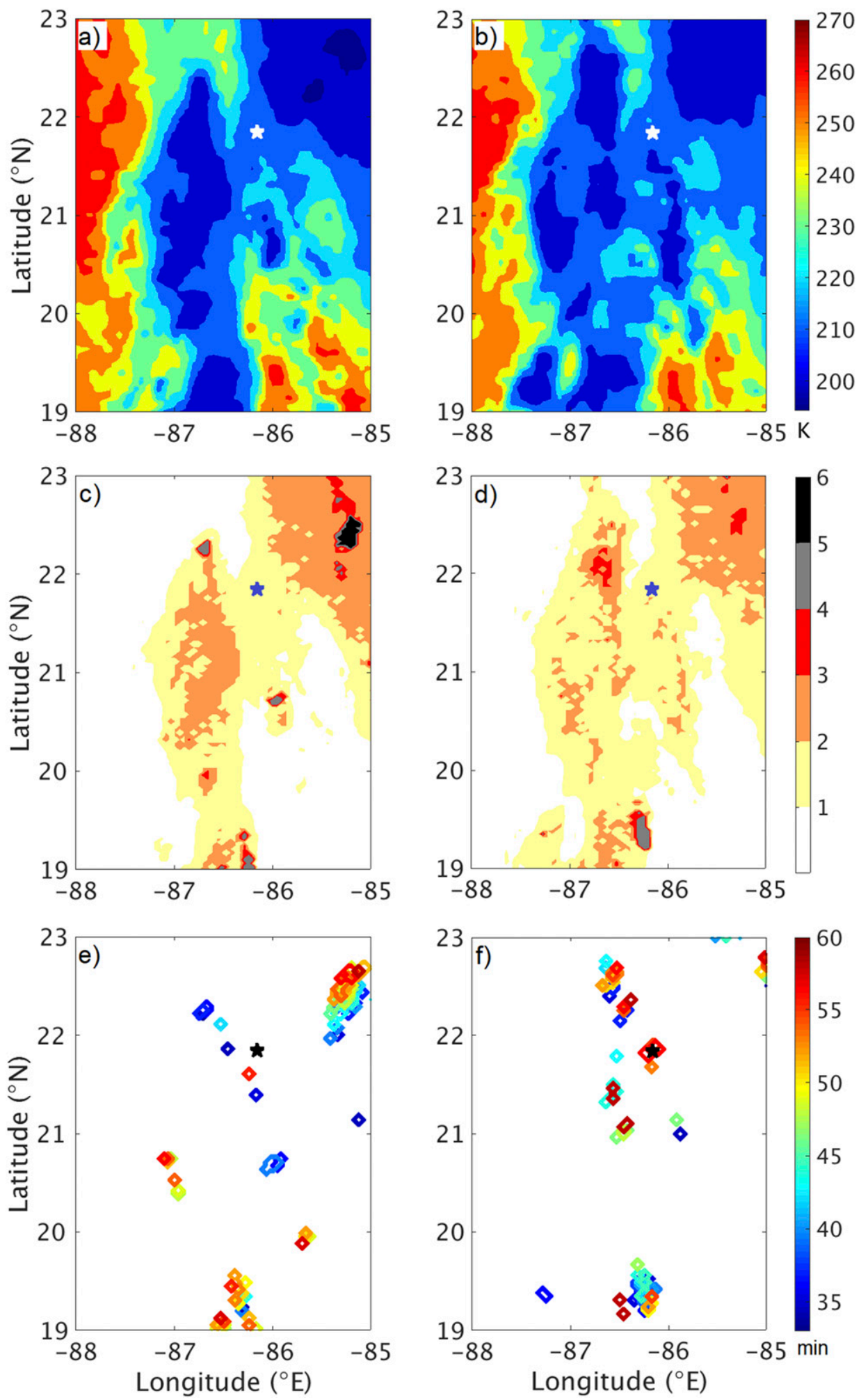

FIG. 3. Observed brightness temperatures (K) from GOES-13 at (a) 1545 and (b) 1645 UTC 20 Jun 2017. (c),(d) The convective diagnosis oceanic algorithm (CDO) hazards at the same times as (a),(b) (threshold descriptors in Table 1). Time (min) of a detected lightning flash during (e) 1530-1600 and (f) 1630-1700 UTC. White (blue and black) stars represent the aircraft location at 1651 UTC. 
TABLE 1. Threshold descriptions of the convective diagnosis oceanic algorithm.

\begin{tabular}{cc}
\hline \hline Threshold & Description \\
\hline 2 & Satellite data only contributed to diagnosis \\
3 & $\begin{array}{c}\text { Lightning but not through the entire analysis period } \\
\text { and no overshooting top }\end{array}$ \\
5 & $\begin{array}{c}\text { Lightning present at the 15th, 30th, and 60th minute } \\
\text { but no overshooting top }\end{array}$ \\
6 & Same as 5, but an overshooting top is present \\
\hline
\end{tabular}

has been shown to be adequate for turbulence prediction (Barber et al. 2018). A 10-km damping layer is used at the model top, which is set to approximately $30 \mathrm{~km}$ $(10 \mathrm{hPa})$. This study uses the Thompson microphysical parameterization, the Tiedke cumulus scheme, and the Mellor-Yamada-Janjić (MYJ) planetary boundary layer scheme (additional parameterization information is provided in Table 2). Simulation output is saved every 10 min to examine convective development, maturity, and dissipation of individual convective cells. The output variables include simulated radar reflectivity which is calculated from the WRF radar routine. The reflectivity calculation routine assumes Rayleigh scattering following the assumptions of the chosen microphysical parameterization scheme (i.e., Thompson in this study).

\section{b. Turbulence diagnostics}

Turbulence diagnostics that are used in this study include the Richardson number, eddy dissipation rate, and second-order structure functions. These indices are chosen based on the environmental conditions of the case day and previous usage in turbulence studies and NCAR's Graphical Turbulence Guidance system (GTG; Sharman and Pearson 2017). Additional indices that are commonly used for diagnosing turbulence including the Brown index (Brown 1973), ColsonPanofsky turbulent kinetic energy metric (Colson and Panofsky 1965), the Dutton index (Dutton 1980), the Ellrod index (T2; Ellrod and Knapp 1992), and the DTF3 index (Marroquin 1998) were also computed for this case day, but will not be discussed due to poor performance. More specifically, the Brown and Ellrod Index suffered resolution sensitivity as was found in Barber et al. (2018).

\section{1) RICHARDSON NUMBER}

While not being able to diagnose turbulence magnitude, numerous past studies have found that Richardson number can diagnose conditions favorable for turbulence production, including shear induced instability and gravity wave breaking (Endlich 1964; Kim and Chun 2011; Trier et al. 2012; Zovko-Rajak and Lane 2014;

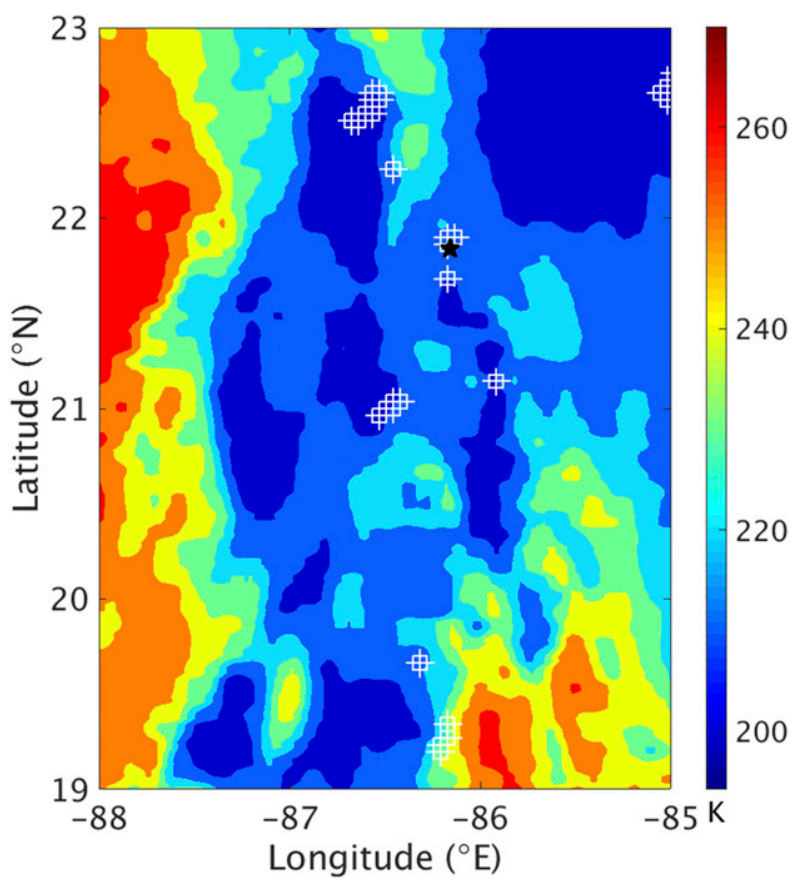

FIG. 4. Earth Networks lightning from 1645 to 5500 UTC (white crosses) and cloud-top temperature (K) from GOES-13 at 1645 UTC. The black star represents the location of the aircraft at 1651 UTC.

Lee and Chun 2018; Trier and Sharman 2018). The gradient Richardson number is expressed as

$$
\mathrm{Ri}=\frac{N^{2}}{S_{v}^{2}}
$$

where

$$
N^{2}=\frac{g}{\theta} \frac{\partial \theta}{\partial z}
$$

Here $S_{v}^{2}$ is the vertical wind shear defined as

$$
S_{v}^{2}=\left(\left|\frac{\partial u}{\partial z}\right|^{2}+\left|\frac{\partial v}{\partial z}\right|^{2}\right)
$$

and $g$ is gravity, $\theta$ is potential temperature $(\mathrm{K})$, and $\partial \theta / \partial z$ is the change of potential temperature with height (Endlich 1964). Ri is indicative of turbulence when it is less than 0.25 . In convection, regions of low $\mathrm{Ri}$ include anvil outflow regions and overshooting tops. The decreasing stability and increase of wind shear in the vicinity of the aircraft on 20 June 2017 motivates the utilization of $\mathrm{Ri}$ as a turbulence diagnostic for this case day.

\section{2) Subgrid-SCALE EDDY Dissipation RATE}

Eddy dissipation rate (EDR or $\varepsilon$ ) is a turbulence intensity metric that can be determined from in-flight wind 


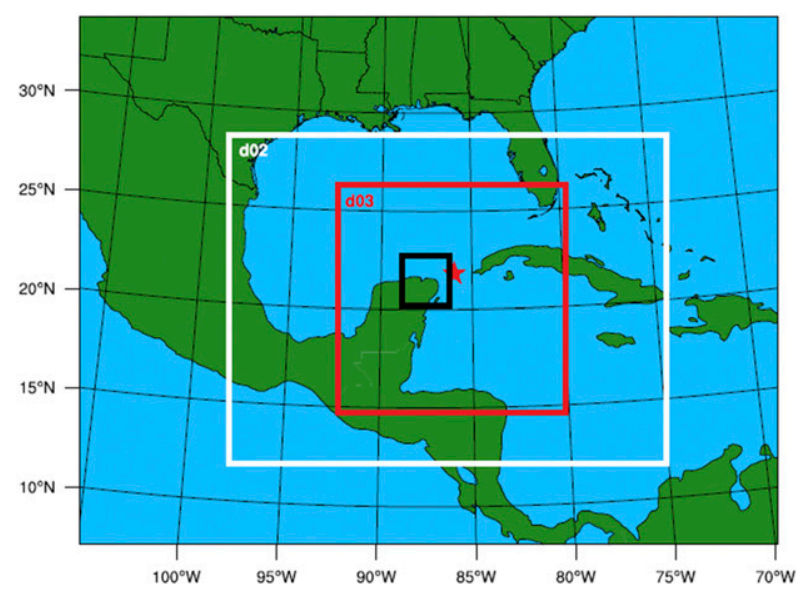

FIG. 5. Model domain for 20 Jun 2017 simulation. D02 represents the first nest within the domain with horizontal grid spacing of $9 \mathrm{~km}$ and D03 represents the innermost nest of the model set up with horizontal grid spacing of $3 \mathrm{~km}$ (red box). Area designated for convective development analysis is represented by the black box. The red star represents the location of the aircraft at 1651 UTC.

measurements (Poellot and Grainger 1991; Emanuel et al. 2013; Sharman et al. 2014; Cornman 2016), from recorded pilot perceived turbulence intensity (PIREPS), from calibrated indices (Brown 1973; Marroquin 1998; Frehlich and Sharman 2004a,b), from simulated fields of turbulent kinetic energy (TKE; Ahmad and Proctor 2012), or from in-cloud measurements of spectral width from weather radar systems (e.g., NEXRAD; Williams and Meymaris 2016). In this study, subgrid-scale EDR (hereafter EDR) is calculated using

$$
\varepsilon^{1 / 3}=\left(\frac{\mathrm{TKE}^{3 / 2}}{L}\right)^{1 / 3}
$$

and is in units of $\mathrm{m}^{2 / 3} \mathrm{~s}^{-1} ; L$ is the length scale defined as

$$
L=(\Delta x \Delta y \Delta z)^{1 / 3},
$$

where $\Delta x$ is the horizontal resolution in the $x$ direction, $\Delta y$ is the horizontal resolution in the $y$ direction, and $\Delta z$ and is the vertical resolution (Schumann 1991; Sharman et al. 2012). The accuracy of $L$ at various model resolutions still remains uncertain and is a limitation of this calculation. In WRF, TKE is subgrid-scale turbulence derived from the vertical component of the velocity and diagnosed by the planetary boundary layer scheme (Janjić 1994). In this study, turbulence intensity thresholds will be defined by Sharman and Pearson (2017) and Pearson and Sharman (2017), which are provided in Table 3. Barber et al. (2018) found EDR to be an accurate indicator of turbulence in northern Great Plains convective simulations, but few tropical studies have included EDR as a turbulence metric. EDR is used as a
TABLE 2. Model parameterizations used in 20 Jun 2017 simulation.

\begin{tabular}{ll}
\hline \multicolumn{1}{c}{ Model physics } & \multicolumn{1}{c}{ Model setup } \\
\hline Microphysics & Thompson \\
Planetary boundary layer & MYJ \\
Surface layer & MM5 \\
Land surface & Noah \\
Shortwave radiation & RRTMG SW \\
Longwave radiation & RRTMG LW \\
Cumulus & Tiedke (D01 and D02) \\
\hline
\end{tabular}

turbulence diagnostic for this case day because it is a common metric used for aviation turbulence prediction (in situ and model derived), is included in GTG, and has been shown to perform well in the midlatitudes.

\section{3) STRUCTURE FUnCTIONS}

Second-order structure functions $D_{s}$ are used in this study as an estimation method for EDR in the inertial range (Kolmogorov 1941; Frehlich and Sharman 2004a,b; Sharman et al. 2006). To compute the second-order structure function (hereafter, SF), the following equations are implemented:

$$
\begin{aligned}
& D_{s(u)}=[u(i+\Delta s)-u(i)]^{2}, \\
& D_{s(v)}=[v(i+\Delta s)-v(i)]^{2},
\end{aligned}
$$

in both the transverse $(x)$ and longitudinal ( $y)$ directions, where $i$ is the grid index, and $s$ is a separation distance expressed in units of spatial grid steps $(d x)$ :

$$
\begin{aligned}
\left\langle D_{s}^{2}\right\rangle & =C_{k} \varepsilon^{2 / 3} \Delta s, \\
\varepsilon^{1 / 3} & =\left(\frac{\left\langle D_{s}^{2}\right\rangle}{\Delta s C_{k}}\right)^{1 / 2} .
\end{aligned}
$$

To calculate $\varepsilon^{1 / 3}$, the average of the four $D_{s}$ components ( $u$ longitudinal, $u$ transverse, $v$ longitudinal, and $v$ transverse, represented by brackets) of $\varepsilon^{2 / 3}$ is taken, where $C_{k}$ equals 2 for the longitudinal direction calculation and $4 / 3 C_{k}$ for the transverse direction (Frehlich and Sharman 2010), and $s$ is chosen as 10 (the maximum spatial lag is 10 grid points). Research has shown that the separation distance should mirror the spectral resolution of the model advection scheme which is be-

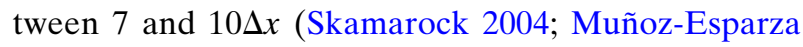
et al. 2018). Turbulence intensity can be determined from the second-order structure functions following the same thresholds as EDR provided in Table 3. The EDR intensity thresholds apply without additional calibration to the structure function values because the structure functions are within the Kolmogorov inertial 
TABLE 3. Turbulence intensity thresholds as determined from the cubed root of eddy dissipation rate ( $\varepsilon$; Sharman and Pearson 2017).

\begin{tabular}{cc}
\hline Turbulence intensity & $\varepsilon^{1 / 3}\left(\mathrm{~m}^{2 / 3} \mathrm{~s}^{-1}\right)$ \\
\hline Light & $0.15-0.22$ \\
Moderate & $0.22-0.34$ \\
Severe & $\geq 0.34$ \\
\hline
\end{tabular}

range (Fig. 6). This study will show the results from the calculation of structure functions with the conversion to EDR [Eq. (9)]. Second-order structure functions are included in the diagnostics analyzed for this case study because they have been shown in past studies to be successful for turbulence prediction (Frehlich and Sharman 2004a,b; Sharman et al. 2006; Sharman and Pearson 2017; Pearson and Sharman 2017; MuñozEsparza et al. 2018), are currently represented in GTG, and can be used to diagnose motions across various scales.

\section{Overview of simulated convection and turbulence predictors}

\section{a. Verification of simulated convection}

The simulated synoptic features of 20 June 2017 include a low pressure center north of the Yucatán Peninsula that deepens with time throughout the simulation. The simulated wind shear along the plane trajectory is both directional and speed shear. In the domain, simulated cloud features include a convective line similar to observations (as shown in Fig. 3a). Simulated cloud-top temperatures (CTTs) calculated using the mixing ratios of the microphysical species from 1500 to 1800 UTC show the vertical convective structure and the intense development and decay of the convective line (Fig. 7). Within the convective line (squall line), embedded cells had CTTs less than $210 \mathrm{~K}$ and a larger area of colder cloud tops to the north of the aircraft. Simulated CTTs were warmer than observed and biased in the western direction (cf. Figs. 7 and 3a,b). This direction bias is important because observed CTTs imply that there were clouds directly below the aircraft while simulated CTTs indicate the aircraft would have been out of cloud with no cloud field underneath near the time of the turbulence encounter. The bias in cloud location and convection also influences the location of simulated turbulence.

The same squall line discussed above is shown using simulated radar reflectivity values (Fig. 8a). The convective line structure has a north-south orientation with a larger complex to the north. The 2-km simulated radar reflectivity values exceed $55 \mathrm{~dB} Z$ in the embedded cells. With regard to the location of the turbulence encounter $\left(21.84^{\circ} \mathrm{N},-86.16^{\circ} \mathrm{E}\right), 2-\mathrm{km}$ simulated radar reflectivity

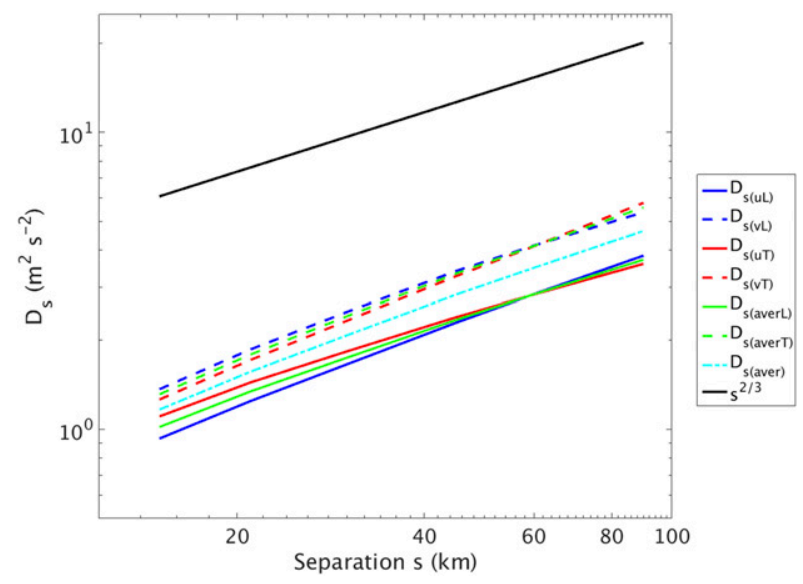

FIG. 6. Structure functions (longitudinal direction: solid lines, transverse direction: dashed lines) as a function of separation distance, and the maximum of the Kolmogorov $2 / 3$ inertial range (black line) for all heights from 1510 to 1800 UTC.

values are zero while directly to the west maximum values exceed $50 \mathrm{~dB} Z$. There is also an area of convection directly to the north of the aircraft's location that was decaying throughout the analysis period. Echo top heights (not shown; calculated from simulated radar reflectivity values with a threshold of $18 \mathrm{dBZ}$ ) that correspond with the regions of maximum $2-\mathrm{km}$ radar reflectivity values exceed $14 \mathrm{~km}$. At the location of the aircraft no echo tops are simulated, but directly to the west a cell developed to heights greater than $14 \mathrm{~km}$ and growth was more than $10 \mathrm{~km}$ during an hour. The analysis of the change of echo top height with time shows the greatest convective development was between 1500 and 1700 UTC. Closest to the aircraft convection was mainly decaying, but numerous cells within $100 \mathrm{~km}$ of the aircraft were rapidly growing.

Lightning was prevalent in the region near the time of the turbulence encounter, specifically around convective cores. Within the region of interest, more than 2000 lightning flashes were recorded by Earth Networks lightning detection network between 1500 and 1800 UTC with the highest frequency between 1600 and 1700 UTC. Near the time of the turbulence encounter lightning was recorded near the trajectory of the aircraft (Fig. 3f). Lightning from the model simulation was determined based on various empirical relationships that relate model variables of maximum updraft velocity, ice water path (column-integrated ice, snow, and graupel mass for temperatures below $-5^{\circ} \mathrm{C}$ ), graupel mass and ice mass fluxes to lightning flash rate (see Barthe et al. 2010 for these relationships). These relationships were adapted to predict lightning densities per $\mathrm{km}^{2}$ for this model simulation by comparing observed lightning densities with the above model parameters (e.g., Allen et al. 2016). 

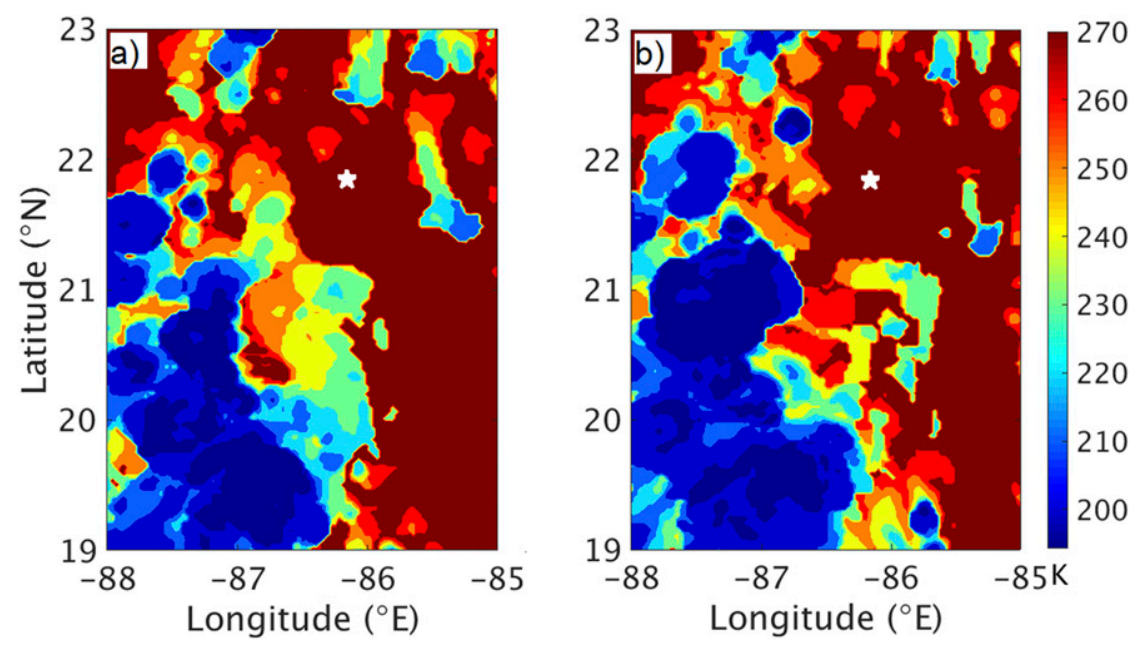

FIG. 7. Simulated cloud-top temperatures (K) at (a) 1600 and (b) 1700 UTC 20 Jun 2017. White stars represent the approximate location of the aircraft at 1651 UTC.

These parameters differ between observational and modeling data and also depend on model simulation setups such as grid spacing and a chosen microphysics scheme. At the time of the turbulence encounter, simulated lightning was frequent within simulated convective cores and anvil cloud regions based various predicted lightning density-model parameter relationships. Figure $8 \mathrm{~b}$ shows an example of predicted lightning density based on ice water path.

In summary, the model simulation was able to capture the morphology of the convective line extending north to south in the Gulf of Mexico and the depth of convection as compared to observations. The simulated convection was intense in nature with echo tops exceeding the typical cruising altitudes of commercial aviation and frequent lightning. While the type of convection, depth, and hazards such as lightning were similar to observations, the location of the convective line was approximately $50 \mathrm{~km}$ too far west as compared to the location of the turbulence encounter. Due to the location bias of convection, the analysis of turbulence will be focused at a hypothetical aircraft location also approximately $50 \mathrm{~km}$ to the west. However, turbulence is still analyzed across the entire domain and the shift in aircraft location only influences the hypothetical flight path. Within figures, this location is designated with a second star.
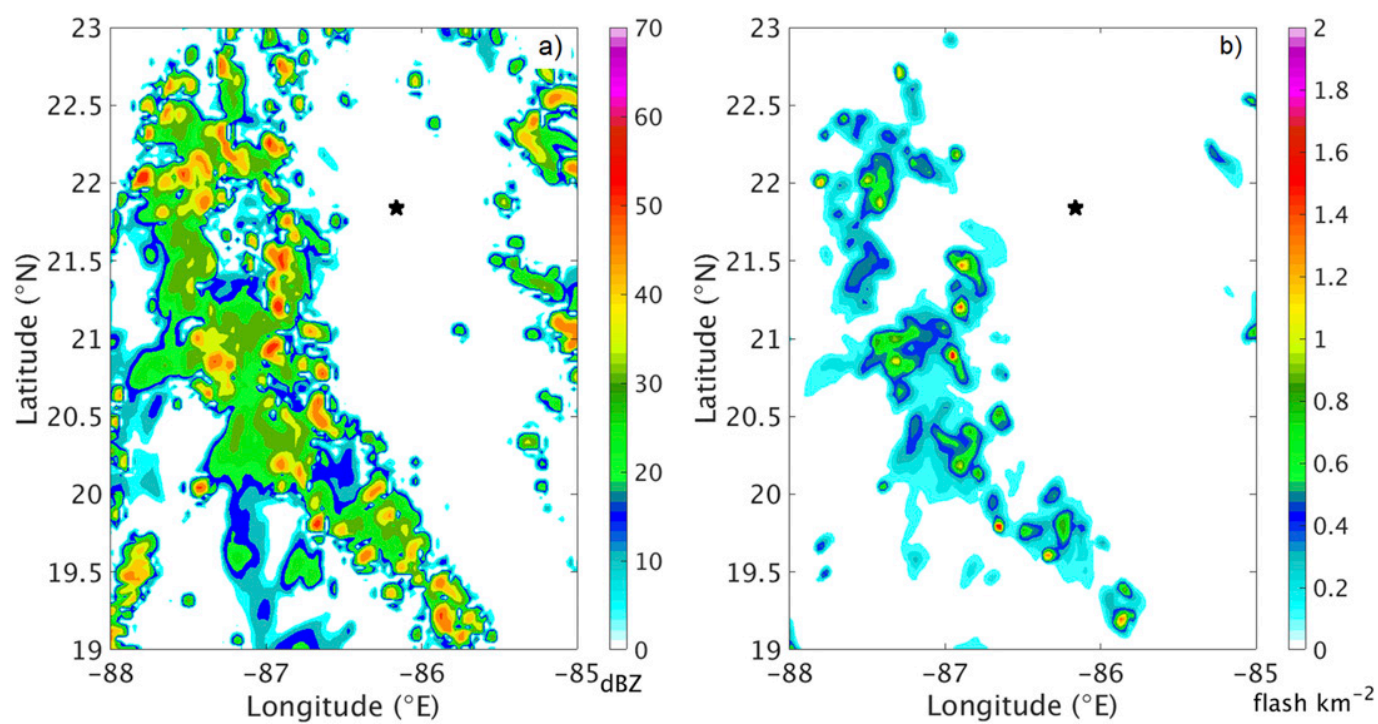

FIG. 8. (a) 2-km simulated radar reflectivity and (b) lightning flash densities per 10 min determined from ice water path at 1650 UTC 20 Jun 2017. Black stars represent the approximate location of the aircraft at 1651 UTC. 


\section{b. WRF-derived turbulence predictors}

Richardson number (Ri), second-order structure functions (SF), and eddy dissipation rate (EDR) are used to diagnose turbulence from the model simulation. The objective of the diagnostic comparison is to examine the performance of each diagnostic in a convective environment where the diagnostics have not been evaluated in previous studies (i.e., the tropics and developing convection). The success of the turbulence diagnostic in the simulated convective environment will motivate the examination of the diagnostic for specific life stages of convection (section 5). Horizontal cross sections of the various indices will focus on the prediction of turbulence between the altitudes of 10,11 (altitude of the aircraft), and $12 \mathrm{~km}$, as these altitudes are common cruising altitudes. Echo top heights are used as a proxy for cloud and an indicator of in-convective-cloud (ICC) or outof-convective-cloud (OCC). More specifically, if an echo top intersects the analysis height, the grid cell at the analysis height is considered in-convective-cloud. If an echo top is less than the analysis height, the grid cell at the analysis height is considered out-of-convective-cloud (following the methodology implemented in Barber et al. 2018).

$\mathrm{Ri}$ is used in this study to indicate regions that are likely turbulent, but cannot be used to differentiate between various intensities of turbulence. Ri indicates areas of turbulence outside of convective regions and the likelihood of turbulence increases with height. In areas where $\mathrm{Ri}$ is less than 0 , analysis of isentropes suggest convectively generated gravity waves began to break. Prior to, during, and after the turbulence encounter, turbulence diagnosed by Ri subtly varies in areal coverage and magnitude. Between 10 and $12 \mathrm{~km}$ in altitude, $\mathrm{Ri}$ less than 0.25 is within $20-50 \mathrm{~km}$ of convective features (Fig. 9a). If Ri was the only diagnostic used as a forecast tool for turbulence avoidance, the altitudes between 10 and $12 \mathrm{~km}$ would be forecasted as a high likelihood of experiencing turbulence within $50 \mathrm{~km}$ of convection and extremely unlikely to the east of the convective line (west of $-86.5^{\circ} \mathrm{E}$ ). The probability of experiencing turbulence increases significantly with height and flying over convection would be hazardous (Lane et al. 2012). Importantly, the turbulence that is diagnosed has a higher likelihood of being OCC than ICC, and is therefore an additional concern to aviation.

Barber et al. (2018) simulated a week of convective cases in North Dakota, in which EDR was shown to reasonably match PIREPS. However, in this case EDR underpredicted intensity of turbulence when compared to the turbulence intensity observed by aircraft (Fig. 9b. EDR rarely exceeded a value of $0.15 \mathrm{~m}^{2 / 3} \mathrm{~s}^{-1}$ or the intensity of light. Similar to $\mathrm{Ri}$, the areal coverage of turbulence increases with height. At the time of the turbulence encounter, there were areas with EDR values between $0.2-0.3 \mathrm{~m}^{2 / 3} \mathrm{~s}^{-1}$ (moderate) between the altitudes of 10 and $12 \mathrm{~km}$, approximately $100 \mathrm{~km}$ to the southwest of the turbulence encounter location. However, between 10 and $12 \mathrm{~km} 10 \mathrm{~min}$ prior to the turbulence encounter and twenty minutes afterward, EDR was less than $0.2 \mathrm{~m}^{2 / 3} \mathrm{~s}^{-1}$ and limited to fewer than 100 grid pixels. If EDR was the sole turbulence diagnostic for this case day, EDR would not have been successful in forecasting turbulence around convection and in clear air regions. Due to this underprediction of turbulence by the EDR diagnostic, it will not be used to analyze turbulence around developing convection (section 5).

Converting SF [Eq. (8)] to EDR units [Eq. (9)] turbulence intensity can be discussed as EDR metrics (Fig. 9c). Relating the converted SF in EDR units to turbulence intensity thresholds provided in Table 3, moderate to severe turbulence is diagnosed between the altitudes of 10 and $12 \mathrm{~km}$. At these altitudes there is moderate turbulence diagnosed near the aircraft location. The most severe turbulence is located to the west and south of the aircraft, with the largest areal coverage of severe turbulence near $19.7^{\circ} \mathrm{N},-87^{\circ} \mathrm{E}$. Very localized regions of moderate-severe turbulence are present substantial distances (more than $50 \mathrm{~km}$ away in the horizontal direction) from cloud boundaries at all heights. The use of SF converted to EDR units aids in assessing the intensity of turbulence that aviation may experience and in this case would have predicted OCC turbulence of moderate intensity near the aircraft.

Turbulence distributions are important indicators of how turbulence diagnostics perform. It is also important to understand ICC and OCC turbulence distributions for aviation applications. SF converted to EDR units [Eq. (15)] between the altitudes of 10 and $12 \mathrm{~km}$ from 1500 to 1800 UTC is provided in Fig. 10 and illustrates the greater areal coverage (nearly an order of magnitude) of OCC turbulence when compared to ICC turbulence. The distribution of OCC turbulence using SF finds nearly $1 \%$ of SF values are light and less than $0.1 \%$ are moderate or severe. The maximum EDR value of ICC turbulence is nearly the same as OCC, but the relative likelihood of experiencing the most severe turbulence while in convective cloud is greater than while out of convective cloud. The greatest hazard remains with out of convective cloud turbulence as pilots generally avoid flying through convective cloud. The distribution of turbulence at various heights (not shown) for a forecast period of 1500 to 1800 UTC highlights that $10 \mathrm{~km}$ in altitude would have the greatest likelihood of experiencing both ICC and OCC turbulence. 

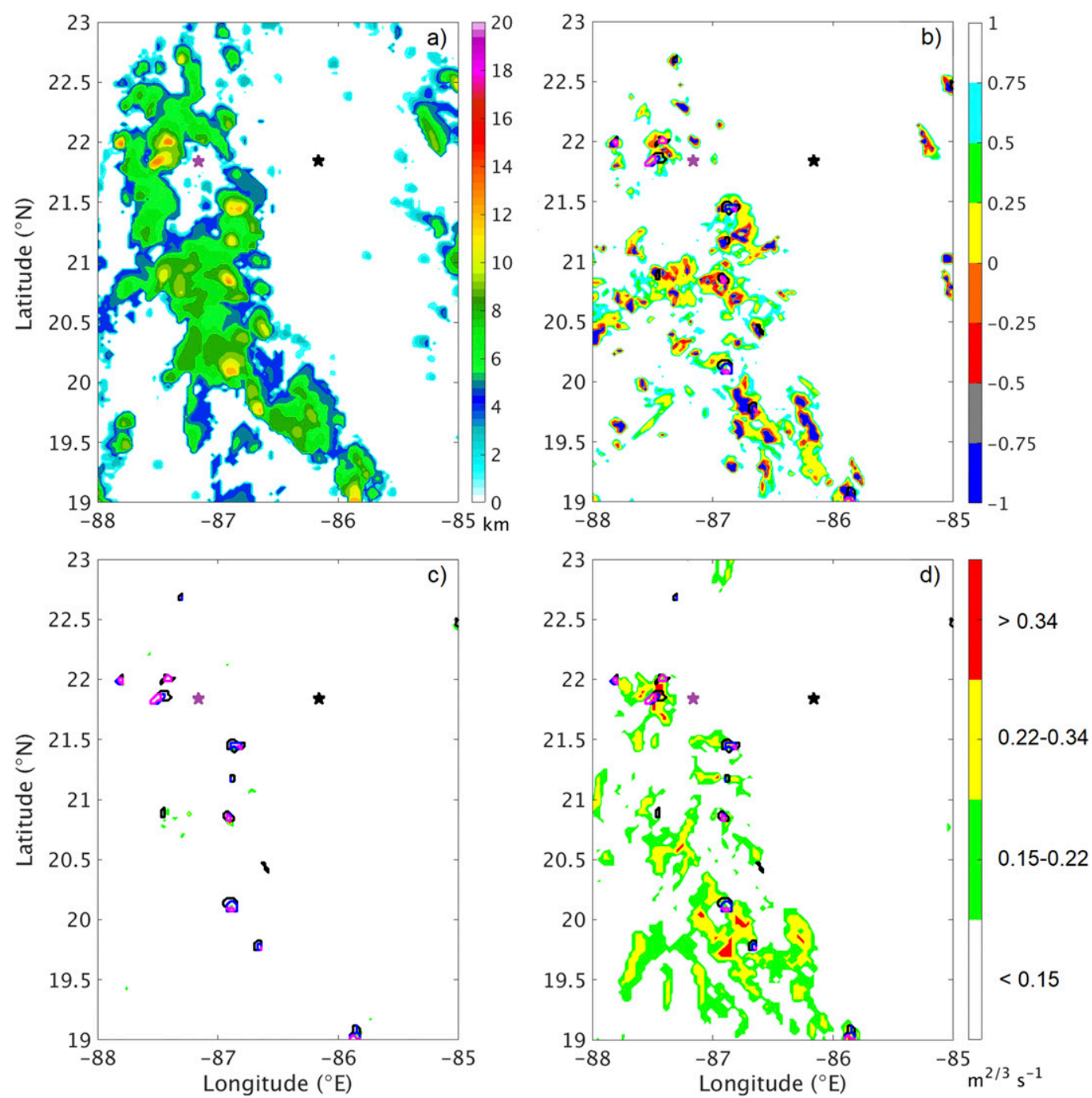

FIG. 9. (a) Simulated echo tops (km) at $1650 \mathrm{UTC}$, and maximum turbulence (minimum for Ri) at 1650 UTC diagnosed by (b) Richardson number, (c) EDR, and (d) $\varepsilon^{1 / 3}$ (structure functions converted to EDR units) between the altitudes of 10 and $12 \mathrm{~km}$. Turbulence intensity is represented by light (green), moderate (yellow), and severe (red) thresholds. Black, blue, and magenta contours represent echo top heights greater than 10, 11, and $12 \mathrm{~km}$. Black (purple) stars represent the aircraft (shifted analysis) location at 1651 UTC.

In summary, Ri and SF performed adequately at diagnosing turbulence near active convection at common cruising altitudes. The majority of turbulence diagnosed is OCC and occurs near the time of the observed turbulence encounter and location. However, the location of turbulence relative to convection does differ between the diagnostics which highlights how the type of turbulence each diagnostic is designed for influences the prediction. SF will be used to diagnose turbulence during the developing stage of convection because of the better performance for the convective environment and because it can be converted to an intensity threshold without requiring any calibration (section 5).

\section{Analysis of turbulence prediction in the vicinity of developing convection}

Numerous meteorological parameters can be used to distinguish between developing, mature, and dissipating convection. Developing convection in past studies has been defined by echo tops that increase in height with time, the presence of an updraft only, vertical growth only, vertical velocities near $10 \mathrm{~m} \mathrm{~s}^{-1}$, insignificant convective rain totals, and the absence of cold rain processes (Byers and Braham 1949; Futyan and Del Genio 2007; Markowski and Richardson 2010; Lin 2010). Mature convection in past studies has been defined as echo tops that reach a maximum in altitude, the presence of an 


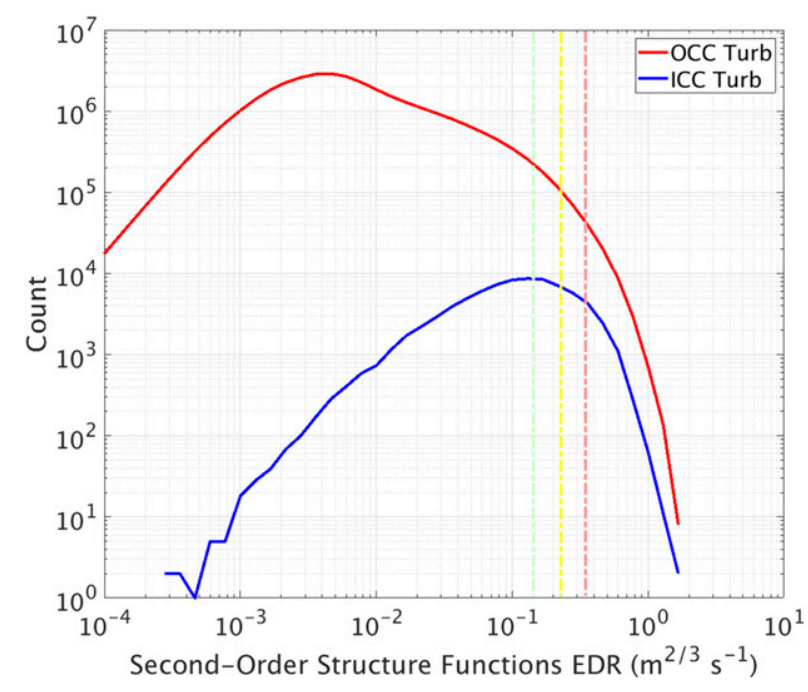

FIG. 10. Count of out-of-convective-cloud (OCC; red) and inconvective-cloud (ICC; blue) turbulent grid cells and probability density functions of OCC and ICC turbulent grid cells calculated from structure functions converted to EDR units from 1500 to 1800 UTC. Vertical dashed lines represent the turbulence intensity thresholds (light: green, moderate: yellow, and severe: magenta).

updraft, downdraft, and anvil, the maximum frequency of lightning, significant convective rain totals, vertical velocities that exceed various percentiles, sustained updraft strength, and maximum areal coverage (Byers and Braham 1949; Tapia et al. 1998; Carey and Rutledge 2000; Markowski and Richardson 2010; Mullendore et al. 2013). In this study, individual convective objects (CO) are defined as contiguous regions with echo tops greater than $8 \mathrm{~km}$ in height. The COs are followed through time using the object's centroid location. A new object is defined if the centroid location of a previous convective object has changed by more than $10 \mathrm{~km}$ in a $10 \mathrm{~min}$ period. Developing convection is defined as a convective object in which the simulated maximum vertical velocity for that object is less than the 90th percentile of all maximum vertical velocities of that object's lifespan and less than the maximum vertical velocity of the following time period. To determine if turbulence is associated with developing convection or mature convection, distance is calculated between the turbulent grid cell and the boundaries of the convective object.

Developing convection is examined by creating a subset within the study domain between the longitudinal range of $-89^{\circ}$ to $-86^{\circ} \mathrm{E}$ and the latitudinal range of $20^{\circ}$ to $23^{\circ} \mathrm{N}$ (black box in Fig. 5). This particular region had numerous convective cells evolving with time and large variations in echo top height. To isolate developing convection from mature and dissipating convection, maximum vertical velocities within convective objects are used as thresholds (as discussed above). From 1510 to 1800 UTC, 77 convective objects were identified as developing and maximum vertical velocities of the objects varied from 3 to $14 \mathrm{~m} \mathrm{~s}^{-1}$. Convection intensified in three distinct periods during 1510-1600, 1600-1710, and 1710-1800 UTC, in which 46 developing convective objects were present in the first active period, 26 in the second active period, and 4 in the third active period. For the convective objects that are identified as mature, the vertical velocity magnitudes in the mature convection (i.e., the 90th percentile of vertical velocity) exceeded $5 \mathrm{~m} \mathrm{~s}^{-1}$ for 24 objects and $10 \mathrm{~m} \mathrm{~s}^{-1}$ for 4 objects, while the mean vertical velocity was $3.86 \mathrm{~m} \mathrm{~s}^{-1}$. The time span for the majority of convective objects identified as developing to transition to mature occurred in $10 \mathrm{~min}$ and the maximum time for development was $40 \mathrm{~min}$.

Out-of-convective-cloud turbulence is analyzed in relationship to the number of $\mathrm{CO}$ that are within $30 \mathrm{~km}$ of the turbulence location. By examining turbulence at $10 \mathrm{~km}$ (the height with the greatest likelihood of experiencing turbulence) in this manner, the influence of convective stage can be further understood in terms of aviation safety. Figure 11 shows the distribution of turbulence values for turbulent grid points that are within $30 \mathrm{~km}$ of CO. The areal coverage of turbulence within $30 \mathrm{~km}$ of only mature/dissipating $\mathrm{CO}$ is greater than the areal coverage of turbulence within $30 \mathrm{~km}$ of both mature/ dissipating and developing CO. However, turbulence intensities are found to be the greatest when developing convection is present in the region. While the exact convective source of turbulence cannot be determined, these results suggest that a flight path near developing convection is likely to experience the most severe turbulence.

Turbulence is then analyzed in relationship to the distance from CO. The distribution of turbulence closest to developing convection demonstrates that the majority of values were less than $0.22 \mathrm{~m}^{2 / 3} \mathrm{~s}^{-1}$ (moderate) at all three analysis heights (Fig. 12) while the most extreme turbulence values were located at $10 \mathrm{~km}$ in altitude. At 11 and $12 \mathrm{~km}$ in altitude, turbulence closest to developing convection does exceed $0.22 \mathrm{~m}^{2 / 3} \mathrm{~s}^{-1}$ (moderate) but occurs at a lower frequency when compared to $10 \mathrm{~km}$ in altitude. Turbulence nearest to mature and dissipating convection is mostly less than $0.22 \mathrm{~m}^{2 / 3} \mathrm{~s}^{-1}$ (moderate) but at a higher frequency than developing convection turbulence (Fig. 12). The majority of severe turbulence is closest to mature convection and is more frequent than severe turbulence closest to developing convection at all three analysis heights (results hold true for various methodologies of defining developing and mature convective objects). However, the grid cells with highest turbulence intensities were collocated with developing convection at $10 \mathrm{~km}$ in altitude (not shown in previous discussion due to analysis procedure). The particular 


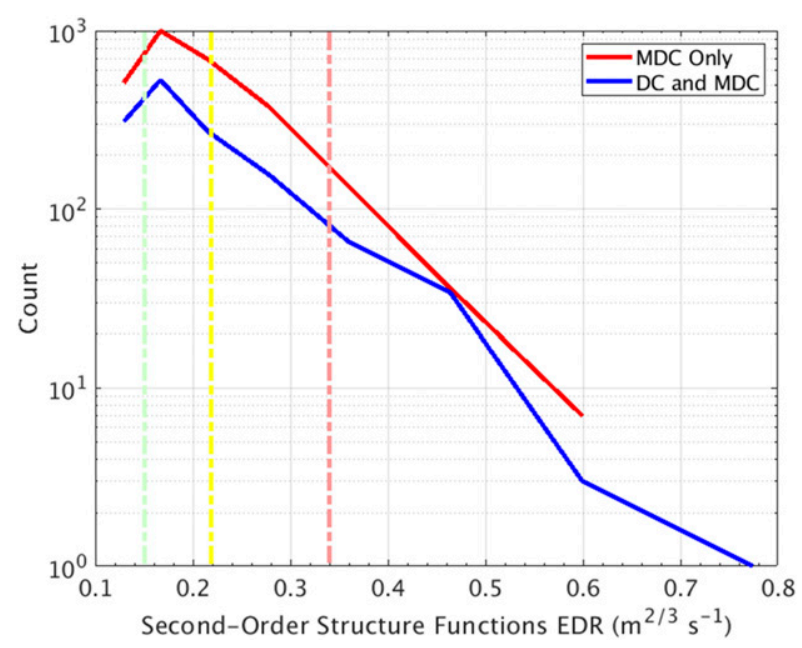

FIG. 11. Distribution of structure functions converted to EDR units where only mature/dissipating (MDC) convective objects are within $30 \mathrm{~km}$ of a turbulent grid point (red) and where both mature/ dissipating and developing convective objects are within $30 \mathrm{~km}$ of a turbulent grid point (blue). Vertical dashed lines represent the turbulence intensity thresholds (light: green, moderate: yellow, and severe: red).

developing $\mathrm{CO}$ that was collocated with the highest turbulence value had maximum vertical velocities increase more than $9 \mathrm{~m} \mathrm{~s}^{-1}$ in $10 \mathrm{~min}$. In addition, echo top heights of the $\mathrm{CO}$ increased more than $3 \mathrm{~km}$ in altitude during the same development period. It can be hypothesized that the rapid development of convection likely formed gravity waves as convection extended in stable regions (Lane et al. 2003); however additional highresolution simulations (spatially and temporally) are needed to adequately examine gravity wave characteristics and determine the exact dynamical cause of the most severe turbulence. While the areal coverage of the most severe turbulent cells collocated with developing convection is very limited, these regions are more dangerous to aviation operations because of lack of avoidance guidelines during developing convective scenarios. One important caveat with this analysis is that turbulence collocated with developing convection may actually be caused by dynamics associated with nearby mature convection. Turbulence can propagate more than $100 \mathrm{~km}$ away from mature convection (USAF 1982; Pantley and Lester 1990; Lane et al. 2003; Lane et al. 2012; ZovkoRajak and Lane 2014; Lane and Sharman 2014), and the particular complexity of this simulation does not allow for the analysis of the primary source of turbulence. More specifically, turbulence collocated with developing convection may not have been caused solely by the developing convection. But we hypothesize that even when mature convection contributes to the turbulence signal, the developing convection is playing an important

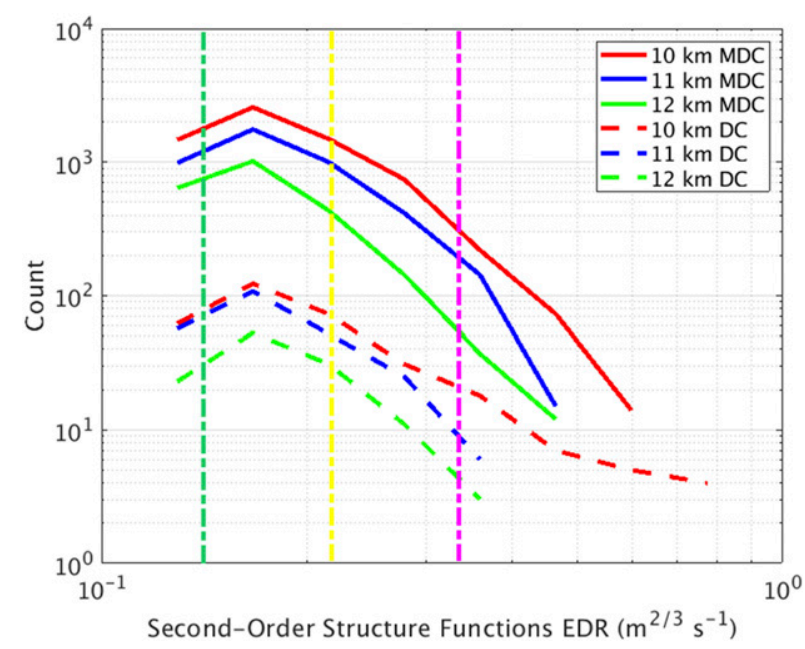

FIG. 12. Distribution of structure functions converted to EDR units closest to developing convection and mature and dissipating convection at 10,11 , and $12 \mathrm{~km}$. Vertical dashed lines represent the turbulence intensity thresholds (light: green, moderate: yellow, and severe: red).

role in modifying (often increasing) the turbulence magnitude, especially in the limited timespan of development in this study. These results highlight that the most severe values of turbulence can be located near developing convection and pilots should use extreme caution around developing convection. These results also stress the necessity of additional research to address the likelihood of turbulence generated by developing convection through the use of high-resolution simulations.

\section{Discussion and conclusions}

Convectively induced turbulence (CIT) prediction is a challenging problem globally and more so in data-sparse regions such as tropical oceans. This study examined turbulence prediction from a WRF simulation for an aviation case that experienced severe turbulence near areas of active convection. Various indices including Richardson number ( $\mathrm{Ri}$ ), subgrid-scale eddy dissipation rate (EDR), and second-order structure functions (SF) were used to diagnose turbulence. These particular indices were chosen as turbulence predictors based on the synoptic and mesoscale conditions of the convective environment. While Ri deduces environments that are favorable for turbulence production, such as sheared environments and gravity wave breaking (Lane et al. 2012), the precise intensity of turbulence that may occur in these regions cannot be determined, limiting the usefulness for aviation operations. However, in stably stratified environments it can be used as a scaling factor for other indices (Sharman and Pearson 2017; MuñozEsparza and Sharman 2018). EDR is a common turbulence 

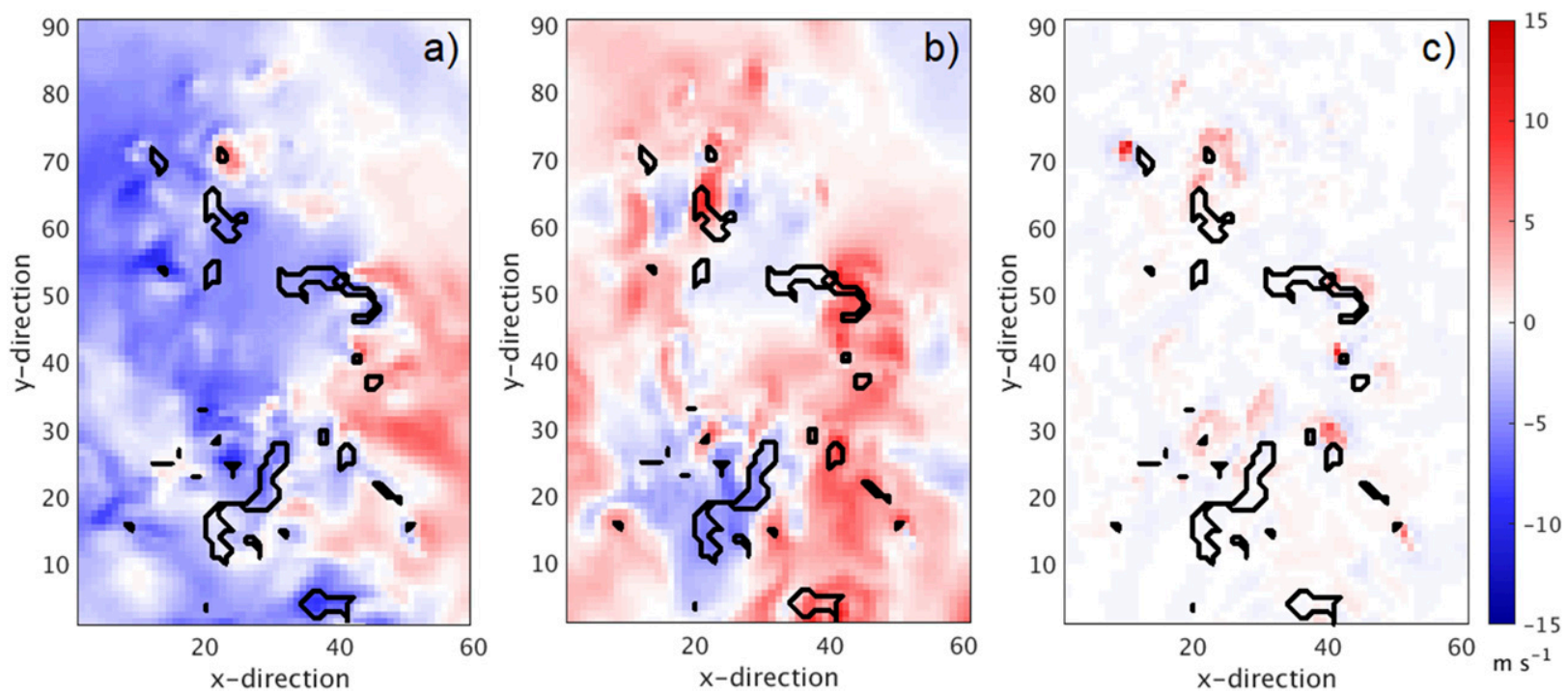

FIG. 13. (a) $U$ component of wind $\left(\mathrm{m} \mathrm{s}^{-1}\right)$, (b) $v$ component of wind $\left(\mathrm{m} \mathrm{s}^{-1}\right.$ ), and vertical velocity ( $\mathrm{m} \mathrm{s}^{-1}$ ) with locations of structure functions converted to EDR units greater or equal to $0.15 \mathrm{~m}^{2 / 3} \mathrm{~s}^{-1}$ (black contour) at $11 \mathrm{~km}$ in altitude.

diagnostic that is physically based and in past studies has predicted turbulence in the midlatitudes accurately (Ahmad and Proctor 2012; Barber et al. 2018). However, in this oceanic study EDR underpredicted turbulence. A limitation with the calculation of EDR is the designation of the length scale. Various methods in past studies have been used including constants, resolution dependent length scales, and direct model output of length scale. Unfortunately, there is no consensus on which approach is the most appropriate for the calculation of EDR. Here, EDR was calculated from the TKE output by the Mellor-Yamada-Janjić PBL scheme; further investigation using PBL schemes more commonly used for WRF simulations for tropical convection is recommended. SF was adequate at diagnosing turbulence near active convection at common cruising altitudes. One problem that may occur through the methodology of calculating structure functions is contamination by the updraft. Figure 13 shows the locations of updraft regions within convective cells, the $u$ and $v$ components of wind, and locations of turbulence at $11 \mathrm{~km}$. Turbulence is located near regions of updrafts (where vertical motions are large), as these regions have perturbations and gradients in both the $u$ and $v$ field. However, turbulence is also found where vertical motions are negligible and only strong gradients in the horizontal component of winds are present.

This study finds that the turbulence indices (both used for CAT and CIT) are limited in accuracy for tropical CIT prediction for this particular case. These results highlight the need for more investigation of tropical turbulence prediction and turbulence diagnostics.
When radar observations and other in situ observations can be utilized, nowcasting products provide the best guidance for turbulence prediction. However, without radar coverage such as in this tropical oceanic case, $\mathrm{SF}$ and $\mathrm{Ri}$ provides guidance to aviation operations in avoiding turbulence, but many more studies of tropical turbulence are needed to statistically verify these indices. More specifically, indices designed for midlatitude continental CIT may not perform as well for tropical oceanic CIT motivating additional studies of diagnostic performance. While this study did not investigate the influence of model resolution on the performance of the turbulence diagnostics, resolution sensitivity is a known limitation of large-scale diagnostics such as the Brown and Ellrod index. Additional research on resolution sensitivity and calibration procedures of turbulence diagnostics is needed as model resolution increases in operational forecasting.

Convection poses a hazard to aviation during multiple stages of the convective life cycle. Forecasting developing convection is difficult due to the limited accuracy of simulated convective initiation, including timing and location. These challenges associated with forecasting developing convection further impact the prediction of turbulence caused by developing convection. Although convective and turbulence ensembles mitigate some of the challenges of forecasting convection in general (Evans et al. 2014; Iyer et al. 2016; Carlberg et al. 2018; Storer et al. 2018), nowcasting is more heavily relied upon for developing convection in aviation applications. In this study, a location bias in the convective feature of approximately $50 \mathrm{~km}$ was 
present, motivating the need for convective ensembles for aviation operations such as flight planning.

This study examined turbulence during an active period of convective growth. Turbulence associated with developing convection was found to represent a small portion of all turbulence during an active convective period. However, turbulence near developing convection was more severe in magnitude than turbulence near mature convection. While most turbulence was found to be associated with mature convection, the severity of turbulence associated with developing convection is likely to influence aviation more as pilots avoid regions with mature convection. To reduce the number of aviation turbulence encounters globally, more research is needed to understand the variation of CIT and the limitations of current prediction systems.

Acknowledgments. We thank the two anonymous reviewers for providing suggestions for improvement of the manuscript. The authors would also like to thank the John D. Odegard School of Aerospace Sciences and the Advanced Study Program for their support of this research. The authors thank Earth Networks for providing the lightning data.

\section{REFERENCES}

Ahmad, N. N., and F. H. Proctor, 2012: Estimation of eddy dissipation rates from mesoscale model simulations. NASA Tech. Rep. AIAA-0429, 24 pp.

AIRBUS, 2007: Flight operations briefing notes: Adverse weather operations: Optimum use of the weather radar. AIRBUS, 17 pp., https://skybrary.aero/bookshelf/books/ 163.pdf.

Allen, B., E. R. Mansell, D. C. Dowell, and W. Deierling, 2016: Assimilation of pseudo geostationary lightning mapper data using the ensemble Kalman filter. Mon. Wea. Rev., 144, 34653486, https://doi.org/10.1175/MWR-D-16-0117.1.

Barber, K. A., G. L. Mullendore, and M. J. Alexander, 2018: Out-ofcloud convective turbulence: Estimation method and impacts of model resolution. J. Appl. Meteor. Climatol., 57, 121-136, https://doi.org/10.1175/JAMC-D-17-0174.1.

Barthe, C., W. Deierling, and M. C. Barth, 2010: Estimation of total lightning from various storm parameters: A cloud-resolving model study. J. Geophys. Res., 115, D24202, https://doi.org/ 10.1029/2010JD014405.

Bluestein, H. B., 1993: Observations and Theory of Weather Systems. Vol. VII, Oxford University Press, 554 pp.

Brown, R., 1973: New indices to locate clear air turbulence. Meteor. Mag., 102, 347-361.

Buldovskii, G. S., S. A. Bortnikov, and M. V. Rubinshtejn, 1976: Forecasting zones of intense turbulence in the upper troposphere. Meteor. Gidrol., 2, 9-18.

Byers, H. R., and R. R. Braham, 1949: The thunderstorm: Report of the Thunderstorm Project. Tech. Rep., U.S. Government Printing Office, Washington, DC, 297 pp.

Carey, L. D., and S. A. Rutledge, 2000: The relationship between precipitation and lightning in tropical island convection:
A C-Band polarmetric radar study. Mon. Wea. Rev., 128, 26872710, https://doi.org/10.1175/1520-0493(2000)128<2687:TRBPAL > 2.0.CO;2.

Carlberg, B. R., W. A. Gallus, and K. J. Franz, 2018: A preliminary examination of WRF ensemble prediction of convective mode evolution. Wea. Forecasting, 33, 783-798, https://doi.org/ 10.1175/WAF-D-17-0149.1.

Chin, H. S., M. M. Bradley, Q. Fu, and C. R. Molenkamp, 1995: Modeling of a tropical squall line in two dimensions: Sensitivity to radiation and comparison with a midlatitude case. J. Atmos. Sci., 52, 3172-3193, https://doi.org/10.1175/15200469(1995)052<3172:MOATSL>2.0.CO;2.

Colson, D., and H. A. Panofsky, 1965: An index of clear-air turbulence. Quart. J. Roy. Meteor. Soc., 91, 507-513, https:// doi.org/10.1002/qj.49709139010.

Cornman, L. B., 2016: Airborne in situ measurements of turbulence. Aviation Turbulence: Processes, Detection, Prediction, R. D. Sharman and T. P. Lane, Eds., Springer, 97-120.

Dutton, M. J. O., 1980: Probability forecasts of clear-air turbulence based on numerical output. Meteor. Mag., 109, 293-310.

Ellrod, G. P., and D. I. Knapp, 1992: An objective clear-air turbulence forecasting technique: Verification and operational use. Wea. Forecasting, 7, 150-165, https://doi.org/10.1175/1520-0434(1992) 007<0150:AOCATF $>2.0 . \mathrm{CO} ; 2$.

— , and J. A. Knox, 2010: Improvements to an operational clearair turbulence diagnostic index by addition of a divergence trend term. Wea. Forecasting, 25, 789-798, https://doi.org/ 10.1175/2009WAF2222290.1.

Emanuel, M., J. Sherry, S. Catapano, L. Cornman, and P. Robinson, 2013: In situ performance standard for eddy dissipation rate. 16th Conf. on Aviation, Range, and Aerospace Meteorology, Austin, TX, Amer. Meteor. Soc., 11.3, https://ams.confex.com/ ams/93Annual/webprogram/Paper219007.html.

Endlich, R. M., 1964: The mesoscale structure of some regions of clear-air turbulence. J. Appl. Meteor., 3, 261-276, https://doi.org/ 10.1175/1520-0450(1964)003<0261:TMSOSR >2.0.CO;2.

Evans, C. D., D. F. V. Dyke, and T. Lericos, 2014: How do forecasters utilize output from a convection-permitting ensemble forecast system? Case study of a high impact precipitation event. Wea. Forecasting, 29, 466-486, https://doi.org/10.1175/ WAF-D-13-00064.1.

FAA, 2017: Safety of flight. Aeronautical information manual: Official guide to basic flight information and ATC procedures, U.S. Department of Transportation, FAA, 435-539, https:// www.faa.gov/air_traffic/publications/media/AIM_Basic_dtd_ 10-12-17.pdf.

Frehlich, R., and R. Sharman, 2004a: Estimates of turbulence from numerical weather prediction model output with applications to turbulence diagnosis and data assimilation. Mon. Wea. Rev., 132, 2308-2324, https://doi.org/10.1175/ 1520-0493(2004)132<2308:EOTFNW > 2.0.CO;2.

$\longrightarrow$, and _ 2004b: Estimates of upper level turbulence based on second order structure functions derived from numerical weather prediction model output. Preprints, 11th Conf. on Aviation, Range, and Aerospace Meteorology, Hyannis, MA, Amer. Meteor. Soc., P4.13, https://ams.confex.com/ams/ 11aram22sls/techprogram/paper_81831.htm.

__, and —_, 2010: Climatology of velocity and temperature turbulence statistics determined from rawinsonde and ACARS/AMDAR data. J. Appl. Meteor. Climatol., 49, 1149-1169, https://doi.org/10.1175/2010JAMC2196.1.

Frierson, D. M. W., 2006: Robust increases in midlatitude static stability in simulations of global warming. Geophys. Res. Lett., 33, L24816, https://doi.org/10.1029/2006GL027504. 
_ - and N. A. Davis, 2011: The seasonal cycle of midlatitude static stability over land and ocean in global reanalyses. Geophys. Res. Lett., 38, L13803, https://doi.org/10.1029/2011GL047747.

Futyan, J. M., and A. D. Del Genio, 2007: Deep convective system evolution over Africa and the tropical Atlantic. J. Climate, 20, 5041-5060, https://doi.org/10.1175/JCLI4297.1.

Garstang, M., and D. R. Fitzjarrald, Eds., 1999: Introduction. Observations of Surface-to-Atmosphere Interactions in the Tropics, Oxford University Press, 3-48.

Herzegh, P., 2002: Development of automated aviation weather products for oceanic/remote regions: Scientific and practical challenges, research strategies, and first steps. Preprints, 10th Conf. on Aviation, Range, and Aerospace Meteorology, Portland, OR, Amer. Meteor. Soc., P3.1, https://ams.confex.com/ ams/13ac10av/techprogram/paper_38762.htm.

Iyer, E. R., A. J. Clark, M. Xue, and F. Kong, 2016: A comparison of 36-60-h precipitation forecasts from convection-allowing and convection-parameterizing ensembles. Wea. Forecasting, 31, 647-661, https://doi.org/10.1175/WAF-D-15-0143.1.

Janjić, Z., 1994: The step-mountain Eta coordinate model: Further developments of the convection, viscous sublayer, and turbulence closure schemes. Mon. Wea. Rev., 122, 927-945, https://doi.org/ 10.1175/1520-0493(1994)122<0927:TSMECM > 2.0.CO;2.

Keller, J. L., 1990: Clear air turbulence as a response to mesoand synoptic-scale dynamic processes. Mon. Wea. Rev., 118, 2228-2242, https://doi.org/10.1175/1520-0493(1990) $118<2228$ :CATAAR $>2.0$. CO; 2 .

Kessinger, C. J., 2017: An update on the convective diagnosis oceanic algorithm. 18th Conf. on Aviation, Range, and Aerospace Meteorology, Seattle, WA, Amer. Meteor. Soc., 211, https://ams.confex.com/ams/97Annual/webprogram/ Paper314031.html.

— for oceanic aviation applications. Proc. SPIE, 7088, 708808, https://doi.org/10.1117/12.795495.

Kim, J., and H. Chun, 2011: Statistics and possible sources of aviation turbulence over South Korea. J. Appl. Meteor. Climatol., 50, 311-324, https://doi.org/10.1175/2010JAMC2492.1.

Knox, J. A., 2001: The breakdown of balance in low potential vorticity regions: Evidence from a clear air turbulence outbreak. Preprints, 13th Conf. on Atmospheric and Oceanic Fluid Dynamics, Breckenridge, CO, Amer. Meteor. Soc., P2.4, https:/ ams.confex.com/ams/13FLUID/webprogram/Paper21099.html.

Koch, S. E., and Coauthors, 2005: Turbulence and gravity waves within an upper-level front. J. Atmos. Sci., 62, 3885-3908, https://doi.org/10.1175/JAS3574.1.

Kolmogorov, A. N., 1941: The local structure of turbulence in incompressible viscous fluid at high Reynolds number. Dokl. Akad. Nauk SSSR, 30, 299-303.

Lane, T. P., and M. J. Reeder, 2001: Modelling the generation of gravity waves by a maritime continent thunderstorm. Quart. J. Roy. Meteor. Soc., 127, 2705-2724, https://doi.org/10.1002/ qj. 49712757810 .

— , and R. D. Sharman, 2008: Some influences of background flow conditions on the generation of turbulence due to gravity wave breaking above deep convection. J. Appl. Meteor. Climatol., 47, 2777-2796, https://doi.org/10.1175/2008JAMC1787.1. , and - 2014: Intensity of thunderstorm-generated turbulence revealed by large-eddy simulation. Geophys. Res. Lett., 41, 2221-2227, https://doi.org/10.1002/2014GL059299.

, - — , T. L. Clark, and H. M. Hsu, 2003: An investigation of turbulence generation mechanisms above deep convection. J. Atmos. Sci., 60, 1297-1321, https://doi.org/10.1175/15200469(2003)60<1297:AIOTGM > 2.0.CO;2.
- J. D. Doyle, R. D. Sharman, M. A. Shapiro, and C. D. Watson, 2009: Statistics and dynamics of aircraft encounters of turbulence over Greenland. Mon. Wea. Rev., 137, 2687-2702, https://doi.org/10.1175/2009MWR2878.1.

, R. D. Sharman, S. B. Trier, R. G. Fovell, and J. K. Williams, 2012: Recent advances in the understanding of near-cloud turbulence. Bull. Amer. Meteor. Soc., 93, 499-515, https:// doi.org/10.1175/BAMS-D-11-00062.1.

Lee, D., and H. Chun, 2018: A numerical study of aviation turbulence encountered on 13 February 2013 over the Yellow Sea between China and the Korean Peninsula. J. Appl. Meteor. Climatol., 57, 1043-1060, https://doi.org/10.1175/JAMC-D-17-0247.1.

Lin, Y.-L., 2010: Isolated convective storms. Mesoscale Dynamics, Cambridge University Press, 272-321.

Liu, C., and E. J. Zipser, 2005: Global distribution of convection penetrating the tropical tropopause. J. Geophys. Res., 110, D23104, https://doi.org/10.1029/2005JD006063.

Marconnet, D., C. Norden, and L. Vidal, 2016: Optimal use of weather radar. 22 pp., http://www.smartcockpit.com/docs/ optimum-use-of-weather-radar-airbus-safety-first-nr22.pdf.

Markowski, P., and Y. Richardson, 2010: Organization of isolated convection. Mesoscale Meteorology in Midlatitudes, WileyBlackwell, 201-244, https://doi.org/10.1002/9780470682104.ch8.

Marroquin, A., 1998: An advanced algorithm to diagnose atmospheric turbulence using numerical model output. 16th Conf. on Weather Analysis and Forecasting, Phoenix, AZ, Amer. Meteor. Soc., 79-81.

Mullendore, G. L., A. J. Homann, S. T. Jorgenson, T. J. Lang, and S. A. Tessendorf, 2013: Relationship between level of neutral buoyancy and dual-Doppler observed mass detrainment levels in deep convection. Atmos. Chem. Phys., 13, 181-190, https:// doi.org/10.5194/acp-13-181-2013.

Muñoz-Esparza, D., and R. Sharman, 2018: An improved algorithm for low-level turbulence forecasting. J. Appl. Meteor. Climatol., 57, 1249-1263, https://doi.org/10.1175/JAMC-D-17-0337.1.

,-- J. Sauer, and B. Kosović, 2018: Toward low-level turbulence forcasting at eddy-resolving scales. Geophys. Res. Lett., 45, 8655-8664, https://doi.org/10.1029/2018GL078642.

Pantley, K. C., and P. F. Lester, 1990: Observations of severe turbulence near thunderstorm tops. J. Appl. Meteor., 29, 11711179, https://doi.org/10.1175/1520-0450(1990)029<1171: OOSTNT $>2.0 . \mathrm{CO} ; 2$.

Pearson, J. M., and R. D. Sharman, 2017: Prediction of energy dissipation rates for aviation turbulence. Part II: Nowcasting convective and nonconvective turbulence. J. Appl. Meteor. Climatol., 56, 339-351, https://doi.org/10.1175/JAMC-D-16-0312.1.

Poellot, M. R., and C. A. Grainger, 1991: A comparison of several airborne measures of turbulence. Preprints, Fourth Int. Conf. on the Aviation Weather Systems, Paris, France, Amer. Meteor. Soc.

Saha, K. R., and S. S. Singh, 1972: On the distribution of mean static stability and mean Richardson number in the tropical atmosphere. J. Meteor. Soc. Japan, 109, 313-323.

Schumann, U., 1991: Subgrid length-scales for large-eddy simulation of stratified turbulence. Theor. Comput. Fluid Dyn., 2, 279-290, https://doi.org/10.1007/BF00271468.

Sharman, R. D., and J. M. Pearson, 2017: Prediction of energy dissipation rates for aviation turbulence. Part I: Forecasting nonconvective turbulence. J. Appl. Meteor. Climatol., 56, 317337, https://doi.org/10.1175/JAMC-D-16-0205.1.

, and S. B. Trier, 2019: Influences of gravity waves on convectively induced turbulence (CIT): A review. Pure Appl. Geophys., 176, 1923-1958, https://doi.org/10.1007/s00024-018-1849-2. 
C. Tebaldi, G. Wiener, and J. Wolff, 2006: An integrated approach to mid- and upper-level turbulence forecasting. Wea. Forecasting, 21, 268-287, https://doi.org/10.1175/ WAF924.1.

— J. D. Doyle, and M. A. Shapiro, 2012: An investigation of a commercial aircraft encounter with severe clear-air turbulence over western Greenland. J. Appl. Meteor. Climatol., 51, 42-53, https://doi.org/10.1175/JAMC-D-11-044.1.

— L. B. Cornman, G. Meymaris, J. Pearson, and T. Farrar, 2014: Description and derived climatologies of automated in situ eddy dissipation rate reports of atmospheric turbulence. J. Appl. Meteor. Climatol., 53, 1416-1432, https://doi.org/ 10.1175/JAMC-D-13-0329.1.

Skamarock, W. C., 2004: Evaluating mesoscale NWP models using kinetic energy spectra. Mon. Wea. Rev., 132, 30193032, https://doi.org/10.1175/MWR2830.1.

- and J. B. Klemp, 2008: A time-split nonhydrostatic atmospheric model for weather and forecasting applications. J. Comput. Phys., 227, 3465-3485, https://doi.org/10.1016/ j.jcp.2007.01.037.

Smith, T. L., S. G. Benjamin, J. M. Brown, S. S. Weygandt, T. Smirnova, and B. E. Schwartz, 2008: Convection forecasts from the hourly updated, 3-km High Resolution Rapid Refresh Model. 24th Conf. on Severe Local Storms, Savannah, GA, Amer. Meteor. Soc., 11.1, https://ams.confex.com/ams/ 24SLS/techprogram/paper_142055.htm.

Storer, L. N., P. G. Gill, and P. D. Williams, 2018: Multi-model ensemble predictions of aviation turbulence. Meteor. Appl., 1, 1002-1041.

Tapia, A., J. A. Smith, and M. Dixon, 1998: Estimation of convective rainfall from lightning observations. J. Appl. Meteor., 37, 1497-1509, https://doi.org/10.1175/1520-0450(1998)037<1497: EOCRFL $>2.0 . C O ; 2$.

Trier, S. B., and R. D. Sharman, 2009: Convection-permitting simulations of the environment supporting widespread turbulence within the upper-level outflow of a mesoscale convective system. Mon. Wea. Rev., 137, 1972-1990, https://doi.org/10.1175/ 2008MWR2770.1.
— aviation turbulence near a convectively enhanced upper-level jet stream. Mon. Wea. Rev., 144, 3003-3027, https://doi.org/ 10.1175/MWR-D-16-0094.1.

$\longrightarrow$, and — 2018: Trapped gravity waves and their association with turbulence in a large thunderstorm anvil during PECAN. Mon. Wea. Rev., 146, 3031-3052, https://doi.org/10.1175/ MWR-D-18-0152.1.

- _ _ - and T. P. Lane, 2012: Influences of moist convection on a cold-season outbreak of clear-air turbulence (CAT). Mon. Wea. Rev., 140, 2477-2496, https://doi.org/10.1175/ MWR-D-11-00353.1.

USAF, 1982: Weather for aircrews. Rep. AFN51-12VI, Vol. 1, USAF, 187 pp.

Vant-Hull, B., W. Rossow, and C. Pearl, 2016: Global comparisons of regional life cycle properties and motion of multiday convective systems: Tropical and midlatitude land and ocean. J. Climate, 29, 5837-5858, https://doi.org/10.1175/ JCLI-D-15-0698.1.

Vogel, G. N., and C. R. Sampson, 1996: Clear air turbulence indices derived from U.S. Navy numerical model data: A verification study. Rep. NRL/MR/7543-96-7223, Naval Research Laboratory, Monterey, CA, $30 \mathrm{pp}$.

Williams, J. K., and G. Meymaris, 2016: Remote turbulence detection using groud-based Doppler radar. Aviation Turbulence: Processes, Detection, Prediction, R. D. Sharman and T. P. Lane, Eds., Springer, 149-177.

Wissmeier, U., and R. Goler, 2009: A comparison of tropical and midlatitude thunderstorm evolution in response to wind shear. J. Atmos. Sci., 66, 2385-2401, https://doi.org/10.1175/ 2009JAS2963.1.

Yuter, S. E., R. A. Houze, A. Smith, T. T. Wilheit, and E. Zipser, 2005: Physical characterization of tropical oceanic convection observed in KWAJEX. J. Appl. Meteor., 44, 385-415, https:// doi.org/10.1175/JAM2206.1.

Zovko-Rajak, D., and T. P. Lane, 2014: The generation of nearcloud turbulence in idealized simulations. J. Atmos. Sci., 71, 2430-2451, https://doi.org/10.1175/JAS-D-13-0346.1. 